\title{
Avoiding postnatal undernutrition of VLBW infants during neonatal intensive care: evidence and personal view in the absence of evidence
}

\author{
Christoph Maas, Christian F Poets, Axel R Franz
}

Department of Neonatology, University Hospital, Tuebingen, Germany

\section{Correspondence to} Dr Christoph Maas,

Department of Neonatology, Tuebingen University Hospital,

Calwerstr. 7, Tuebingen

72076, Germany;

Christoph.Maas@med.unituebingen.de

Received 15 May 2014 Revised 10 September 2014 Accepted 14 September 2014 Published Online First 3 October 2014

\section{ABSTRACT}

Inadequate nutrient intakes in the first postnatal weeks play a crucial role in the aetiology of postnatal growth restriction of very low birthweight (VLBW) infants. Efforts to improve early nutrition in these infants led to a significant reduction in postnatal growth failure. Initiation of enhanced parenteral nutrition immediately after birth and utilisation of the large potential of early enteral nutrition seem pivotal. Nevertheless, it remains challenging to further reduce the initial drop in weight and head circumference z-score and to improve body composition and linear growth. This review will summarise data on how near-fetal postnatal weight gain in VLBW infants can be achieved and makes suggestions for early nutrition of VLBW infants.

\section{INTRODUCTION}

Faltering growth of very low birthweight (VLBW) infants during postnatal hospitalisation is associated with impaired neurodevelopment, ${ }^{1-3}$ increased risk of retinopathy of prematurity, ${ }^{4}$ persistent growth deficits $^{5}$ and increased risk for cardiovascular disease in adulthood. ${ }^{5-7}$ Although the aetiology of poor postnatal growth in VLBW infants is multifactorial, inadequate nutrient intake, particularly during the first postnatal weeks, plays a crucial role. ${ }^{89}$ Additionally, associations between postnatal energy and protein intake and developmental outcomes as well as brain volume were demonstrated. ${ }^{10-12}$ A recent randomised controlled trial showed better head growth in very preterm infants throughout the first postnatal month with higher protein and calorie intake. ${ }^{13}$

Efforts to improve early nutrition of VLBW infants resulted in a significant reduction in postnatal growth failure, and recent studies from selected centres showed that regaining birth-growth-trajectories for weight and head circumference until term-corrected age is feasible in most infants. ${ }^{14-18}$ In these studies, an initial decline in weight and head circumference $\mathrm{z}$-scores was followed by a progressive return towards the birth z-score until discharge, indicating that regular fetal weight gain and head growth can also be achieved during neonatal intensive care. In contrast, a recent population-based study from the UK still showed substantial deceleration in weight gain after preterm birth in relation to fetal growth rates with "mean weight crossing centiles downwards by at least two centile channel widths". ${ }^{19}$

In the absence of conclusive evidence which postnatal growth pattern is ideal for VLBW infants in the long-term regarding metabolic health and intact neurodevelopment, but supported by the epidemiological data outlined above, we adhere to the unproven hypothesis that growth should approximate that of the healthy fetus in rate and body composition. Although regular fetal weight gain and head growth can be achieved until discharge (table 1 and refs. ${ }^{14-18}$ ), it remains challenging to further reduce the initial drop in weight and head circumference $\mathrm{z}$-score and to improve body composition and linear growth.

This review summarises recent data on postnatal weight gain and head growth in VLBW infants approximating that of fetal growth charts (in the following abbreviated as 'near-fetal') and future prospects to further improve early postnatal growth. Additionally, recommendations for early nutrition of VLBW infants based on the results of recent studies will be given, keeping in mind that the consequences of such practice on long-term metabolic health and neurodevelopment are yet unknown. Therefore these recommendations can only be regarded as preliminary.

\section{NUTRITIONAL FACTORS CONTRIBUTING TO A REDUCTION IN POSTNATAL GROWTH FAILURE OF VLBW INFANTS}

Is there a consistent pattern among interventional and observational studies reporting near-fetal postnatal growth?

There is evidence from meta-analyses that early parenteral nutrition of VLBW infants reduces postnatal weight loss and shortens time to regain birth weight. $^{20}$ Several recent randomised controlled trials (RCTs), however, failed to show improved growth during the initial hospitalisation in infants randomised to enhanced nutrition, ${ }^{17}{ }^{21}$ potentially because the nutritional goals these studies aimed for had not been achieved and/or the intervention period while infants received parenteral nutrition were too short to reveal longer-lasting effects. Another recent RCT provided evidence that an increased parenteral protein and energy supply during the 1 st days yielded significantly better head growth, ${ }^{13}$ but participating infants experienced a significant fall in SD score (SDS) for weight from birth until 36 weeks postmenstrual age despite a favourable head growth, possibly indicating that also the enteral feeding regimen requires careful attention. Another recent RCT on enhanced feeding ${ }^{18}$ showed significantly better weight gain throughout the postnatal hospitalisation and adequate catch-up growth for head circumference in the intervention group. Unfortunately, this trial was truncated early for a higher incidence of septicaemia in the intervention group and relevant 
Table 1 Selected studies reporting near-fetal postnatal weight gain in VLBW infants

\begin{tabular}{|c|c|c|c|c|c|c|c|c|}
\hline Authors & $\begin{array}{l}\text { Publication year } \\
\text { Study type } \\
\text { Study period } \\
\text { Patients }\end{array}$ & Nutritional intervention & $\begin{array}{l}\text { Number of } \\
\text { infants }\end{array}$ & $\begin{array}{l}\text { Mean gestational } \\
\text { age at birth } \\
\text { (weeks) }\end{array}$ & $\begin{array}{l}\text { Mean birth } \\
\text { weight }(g)\end{array}$ & $\begin{array}{l}\text { Information on combined } \\
\text { enteral and parenteral } \\
\text { energy supply }\end{array}$ & $\begin{array}{l}\text { Information on combined } \\
\text { enteral and parenteral } \\
\text { protein intake }\end{array}$ & Enteral nutrition \\
\hline $\begin{array}{l}\text { Senterre and Rigo }{ }^{14} \\
\text { complemented by } \\
\text { (personal communication) }\end{array}$ & $\begin{array}{l}2011 \\
\text { observational } \\
2006-2007 \\
\text { VLBWI }\end{array}$ & $\begin{array}{l}\text { Optimised early nutritional } \\
\text { support }\end{array}$ & 102 & 28.5 & 1005 & $\begin{array}{l}\text { Mean cumulative energy } \\
\text { intakes until day } 28: \\
3156.4 \pm 310.1 \mathrm{kcal} / \mathrm{kg}\end{array}$ & $\begin{array}{l}\text { Mean cumulative protein } \\
\text { intakes until day } 28: \\
104.1 \pm 7.1 \mathrm{~g} / \mathrm{kg}\end{array}$ & $\begin{array}{l}\text { Mean enteral intake at } \\
1 \text { week: } \\
41 \mathrm{~mL} / \mathrm{kg} / \mathrm{d} \\
\text { PN discontinued on d } 28 \\
\text { (mean) }\end{array}$ \\
\hline $\begin{array}{l}\text { Moltu et al }{ }^{18} \\
\text { complemented by } \\
\text { (personal communication) }\end{array}$ & $\begin{array}{l}2014 \\
\text { RCT } \\
2010 \\
\text { VLBWI }\end{array}$ & Enhanced feeding & 23 & 28.1 & 936 & $\begin{array}{l}\text { Mean average energy intake } \\
\text { until day 28: } \\
139 \mathrm{kcal} / \mathrm{kg} / \mathrm{d}\end{array}$ & $\begin{array}{l}\text { Mean average protein intake } \\
\text { until day 28: } \\
4.0 \mathrm{~g} / \mathrm{kg} / \mathrm{d}\end{array}$ & $\begin{array}{l}\text { Fortified full enteral } \\
\text { feeding after a median of } \\
11 \mathrm{~d}\end{array}$ \\
\hline Vlaardingerbroek et al ${ }^{17}$ & $\begin{array}{l}2013 \\
\text { RCT } \\
2008-2012 \\
\text { VLBWI }\end{array}$ & High AA+lipids & 47 & 27.2 & 867 & $\begin{array}{l}\text { Mean energy intake on day } 6 \text { : } \\
90.4 \pm 23 \mathrm{kcal} / \mathrm{kg} / \mathrm{d}\end{array}$ & $\begin{array}{l}\text { Mean protein intake on day } 6 \text { : } \\
3.0 \pm 1.0 \mathrm{~g} / \mathrm{kg} / \mathrm{d}\end{array}$ & $\begin{array}{l}\text { Full enteral feeding after } \\
\text { a median of } 15 d\end{array}$ \\
\hline Loys et $a l^{15}$ & $\begin{array}{l}2013 \\
\text { observational } \\
2009 \\
\text { ELBWI and GA } \\
<28 \text { weeks }\end{array}$ & Modified nutritional policy & 37 & 26 & 780 & $\begin{array}{l}\text { Mean energy intake on day } 7 \text { : } \\
\approx 70 \mathrm{kcal} / \mathrm{kg} / \mathrm{d}^{*} \\
\text { and on day } 28: \\
\approx 130 \mathrm{kcal} / \mathrm{kg} / \mathrm{d}^{*}\end{array}$ & $\begin{array}{l}\text { Mean protein intake on day } 7 \text { : } \\
\approx 3.2 \mathrm{~g} / \mathrm{kg} / \mathrm{d}^{*} \\
\text { and on day } 28 \text { : } \\
\approx 3.7 \mathrm{~g} / \mathrm{kg} / \mathrm{d}^{*}\end{array}$ & $\begin{array}{l}\text { Enteral feeding increased } \\
\text { at a rate of } 12 \mathrm{~mL} / \text { day }\end{array}$ \\
\hline $\begin{array}{l}\text { Maas et } a^{16} \\
\text { complemented by } \\
\text { (unpublished data) }\end{array}$ & $\begin{array}{l}2013 \\
\text { observational } \\
2010 \\
\text { VLBWI and GA } \\
<32 \text { weeks }\end{array}$ & $\begin{array}{l}\text { Accelerated advancement } \\
\text { of enteral feeding volumes }\end{array}$ & 92 & $27.7 \dagger$ & $894 \dagger$ & $\begin{array}{l}\text { Mean energy intake on day } 7 \text { : } \\
105 \mathrm{kcal} / \mathrm{kg} / \mathrm{d} \\
\text { Mean cumulative energy } \\
\text { intakes until day } 28: \\
3454 \pm 424 \mathrm{kcal} / \mathrm{kg} \dagger\end{array}$ & $\begin{array}{l}\text { Mean protein intake on day } 7 \text { : } \\
3.8 \mathrm{~g} / \mathrm{kg} / \mathrm{d} \\
\text { Mean cumulative protein } \\
\text { intakes until day } 28 \text { : } \\
109.1 \pm 11.7 \mathrm{~g} / \mathrm{kg} \dagger\end{array}$ & $\begin{array}{l}\text { Full enteral feeding after } \\
\text { a median of } 6 d\end{array}$ \\
\hline
\end{tabular}

*Data extracted from figure.

erted in the original publication.

AA, amino acids; ELBWI, extremely low birth weight infants; GA, gestational age; PN, parenteral nutrition; RCT, randomised controlled trial; VLBWI, very low birthweight infants. 
Table 2 Selected studies reporting near-fetal weight gain: weight and head circumference z-score change

\begin{tabular}{|c|c|c|c|c|}
\hline Authors & $\begin{array}{l}\text { Weight z-score } \\
\text { change } \\
\text { until day } 28 \text { (mean) }\end{array}$ & $\begin{array}{l}\text { Weight z-score change } \\
\text { until discharge/ } \\
36 \text { weeks } \\
\text { PMA (mean) }\end{array}$ & $\begin{array}{l}\text { Head circumference } \\
\text { z-score change } \\
\text { until } \\
\text { day } 28 \text { (mean) }\end{array}$ & $\begin{array}{l}\text { Head circumference z-score } \\
\text { change until discharge/ } \\
36 \text { weeks } \\
\text { PMA (mean) }\end{array}$ \\
\hline $\begin{array}{l}\text { Senterre and Rigo }{ }^{14} \text { complemented by } \\
\text { (personal communication) }\end{array}$ & -0.51 & $-0.26 /$ n.a. & -0.82 & -0.11/n.a. \\
\hline $\begin{array}{l}\text { Moltu et } a l^{18} \text { complemented by (personal } \\
\text { communication) }\end{array}$ & -0.29 & n.a./0.08 & n.a. & n.a./0.63 \\
\hline Vlaardingerbroek et $\mathrm{a} \mathrm{l}^{17}$ & -1.55 & $-0.03 /$ n.a. & -0.9 & 0.6/n.a. \\
\hline Loys et $a l^{15}$ & $\approx-0.4^{*}$ & n.a./ $\approx-0.03^{*}$ & $\approx-1.15^{*}$ & n.a. $/ \approx-0.8^{*}$ \\
\hline Maas et $a l^{16}$ complemented by (unpublished data) & -0.62 & $-0.13 /$ n.a. & -0.84 & $-0.08 /$ n.a. \\
\hline
\end{tabular}

electrolyte disturbances emerged, ${ }^{22}$ so again further improvement of the applied nutritional regimen seemed necessary.

Several recent observational and interventional studies in VLBW infants demonstrated that, after falling away from the birth centile, regaining of the initial birth trajectories for weight and head circumference growth until term-corrected age, that is, near-fetal growth, can be achieved. Nevertheless, it is yet unknown how nutritional practices resulting in near-fetal postnatal growth affect long-term outcome of these infants in terms of metabolic health or neurodevelopment.

Findings of an admittedly non-systematic selection of studies that reported near-fetal postnatal weight gain and head growth based on SDSs and clearly described the actual (rather than intended) nutritional support are summarised in tables 1 and 2. Common denominators in these studies were the introduction of enhanced parenteral nutrition immediately after birth including the start of intravenous lipids on the first postnatal day. Although there was still remarkable heterogeneity regarding the advancement of parenteral macronutrient supply, a mean total energy supply of $70 \mathrm{kcal} / \mathrm{kg} / \mathrm{d}$ to $113 \mathrm{kcal} / \mathrm{kg} / \mathrm{d}$ and total protein supply of $3.0 \mathrm{~g} / \mathrm{kg} / \mathrm{d}$ to $3.8 \mathrm{~g} / \mathrm{kg} / \mathrm{d}$, respectively, was achieved by 1 week of age. Four studies reported cumulative mean energy and protein supply during the first 4 weeks ranging from 112 $\mathrm{kcal} / \mathrm{kg} / \mathrm{d}$ to $139 \mathrm{kcal} / \mathrm{kg} / \mathrm{d}$ and $3.7 \mathrm{~g} / \mathrm{kg} / \mathrm{d}$ to $4.0 \mathrm{~g} / \mathrm{kg} / \mathrm{d}$ protein. Among these studies, the smallest decline in SDS for weight during the first 4 weeks was observed in the group with the highest energy and protein supply ${ }^{18}$ (see tables 1 and 2).

In addition to differences in parenteral nutrient supply, disparity in enteral nutrition policies is particularly striking: whereas a mean enteral intake of $41 \mathrm{~mL} / \mathrm{kg} / \mathrm{d}$ was achieved until day 7 in one study, ${ }^{14}$ full enteral feeds (ie, $>140 \mathrm{~mL} / \mathrm{kg} / \mathrm{d}$ ) were achieved within 6 days after birth in another. ${ }^{16}$ Despite very early transition to full enteral feeds, favourable growth outcomes were achieved in two cohorts. ${ }^{16} 18$ Only minor differences in SDS change for weight and head circumference between birth and day 28 emerged between the cohort with the longest time on parenteral nutrition ${ }^{14}$ and that with the shortest time to full enteral feeds ${ }^{16}$ (see tables 1 and 2). Thus, both policies seem possible if one aims to optimise postnatal growth.

\section{PARENTERAL NUTRITION}

\section{Amino acids}

Evidence from meta-analysis ${ }^{23}$ and recent RCTs ${ }^{13} 172124$ suggests that current neonatal amino acid formulations can be introduced immediately after birth without metabolic complications. Several trials showed higher blood urea nitrogen levels due to enhanced amino acid oxidation if a supply of 3.6-4.0 g/ $\mathrm{kg} / \mathrm{d}$ was targeted. ${ }^{17}{ }^{21}$ Despite findings of an improved nitrogen balance and a more anabolic state with higher amino acid supply, recent RCTs failed to demonstrate improved short-term growth, ${ }^{17}{ }^{21}$ potentially because the targeted amino acid intake was not reached. In contrast, others demonstrated improved head growth by optimising protein and energy supply, ${ }^{13}$ although weight gain was not significantly improved. In addition to conflicting data on the influence of amino acid supply on short-term growth, there are yet no data from RCTs suggesting that an enhanced amino acid supply would improve long-term or neurodevelopmental outcome. On the other hand, failure to provide adequate intakes of protein and energy during the first postnatal week was associated with negative effects on neurocognitive outcome in observational studies. ${ }^{11}$

In the selected studies achieving near-fetal postnatal growth (table 1), amino acids were supplied immediately after birth at a dose of $1.4 \mathrm{~g} / \mathrm{kg} / \mathrm{d}^{15}$ to $3.6 \mathrm{~g} / \mathrm{kg} / \mathrm{d} .^{17}$ Our approach and suggestions for the introduction and advancement of amino acids are summarised in figure 1.

\section{Lipid emulsions}

Intravenous lipids are an important source of energy because of their high energy density. They may be administered to deliver calories required for protein synthesis and essential fatty acids such as docosahexaenoic acid and arachidonic acid that seem crucial for the rapidly developing central nervous system. In the past, the use of parenteral lipids has been restricted due to safety concerns and the fear of an impaired lipid tolerance. A recent meta-analysis concluded that starting parenteral lipids within the first two postnatal days is well tolerated but does not offer significant growth advantages during the initial hospitalisation. ${ }^{25}$ However, more recent RCTs on parenteral lipids initiated at day 1 did show effects on growth; one in terms of decreased postnatal weight loss and earlier regain of birth weight with a higher dose of intravenous lipids, ${ }^{26}$ the other in terms of better initial weight gain and head growth associated with the use of a multicomponent fat emulsion. ${ }^{27}$ Currently, there are no RCT data on the effect of intravenous lipids on long-term development of preterm infants.

In terms of essential fatty acid supply ${ }^{27}$ and prevention of nosocomial infection, ${ }^{25} 27$ it might be favourable to use newer multicomponent lipid emulsions. Evidence from animal studies suggests that these lipid emulsions might be advantageous in terms of prevention of parenteral nutrition associated liver disease (PNALD) as well. ${ }^{28}$ 
Figure 1 Guide to early parenteral nutrition-a personal view.
Guide to early parenteral nutrition - a personal view
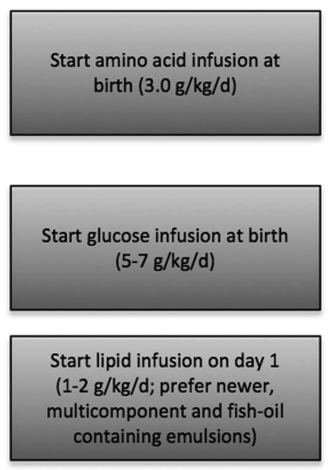
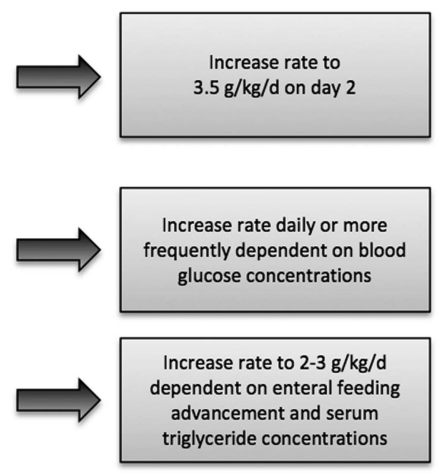
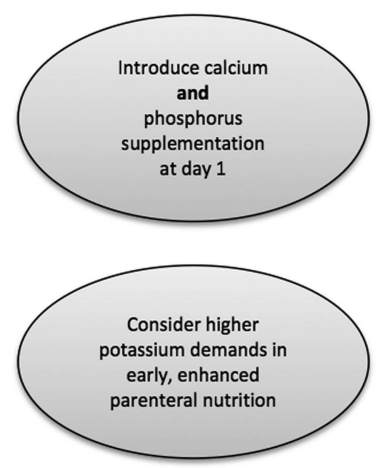

\section{Glucose and insulin}

Starting glucose infusion immediately after birth aims at preventing neonatal hypoglycaemia and providing adequate amounts of calories. Based on the studies achieving near-fetal postnatal growth summarised in table 1, an initial dose of 5-7 g/ $\mathrm{kg} / \mathrm{d}$ of glucose is advisable, with a periodic increase in glucose infusion rate up to a maximum of $13-16-(18) \mathrm{g} / \mathrm{kg} / \mathrm{d}$ as long as normoglycaemia is maintained. ${ }^{29}$ Current evidence from meta-analysis does not support routine use of early continuous insulin infusion to prevent hyperglycaemia and promote anabolism in VLBW infants, ${ }^{30}$ and insulin was also not routinely used in the studies summarised in table 1.

\section{Electrolyte disturbances encountered with earlier and enhanced parenteral nutrition}

With early and enhanced postnatal parenteral nutrition, electrolyte disturbances emerged in the first postnatal days that were formerly considered unusual. Obviously, starting at a higher amino acid intake influences calcium and phosphorus homoeostasis in preterm infants potentially leading to hypophosphataemia and hypercalcaemia. ${ }^{22} 31$ These disturbances are probably linked to an earlier and enhanced anabolism entailing a higher phosphorus demand. ${ }^{31}$ Additionally, rapidly growing cells will need large amounts of potassium. Accordingly, careful adjustment of the electrolytes particularly relevant to enhanced early parenteral nutrition and adequate potassium and phosphorus supplementation should be considered earlier than recommended in existing guidelines. ${ }^{29}$ Clearly, calcium and phosphorus are necessary components of parenteral nutrition in VLBW infants starting on the day of birth. ${ }^{32}$

\section{Discontinuation of parenteral nutrition}

With advancement of enteral feeds, parenteral nutrition is gradually replaced by enteral nutrition as a major nutrient source. In the selected studies achieving near-fetal postnatal weight gain with available information on this issue (table 1), parenteral nutrition was discontinued when enteral feeding reached $120-150 \mathrm{~mL} / \mathrm{kg} / \mathrm{d}$.

\section{ENTERAL NUTRITION}

\section{Initiation of enteral feeding}

Early enteral nutrition may decrease gut atrophy and promote gastrointestinal maturation with the release of hormones that stimulate intestinal villous growth and motor function in preterm infants, especially when human milk is used. In the past, the notion that enteral feeding may cause necrotising enterocolitis (NEC) often prevented early enteral nutrition. A recent meta-analysis concluded that there is no evidence that delaying enteral feeding in VLBW infants reduces the risk of NEC. ${ }^{33}$ It therefore seems reasonable to start enteral feeding on day 1 and, whenever possible, with human milk.

\section{Enteral feeding advancement}

Potential benefits of early transition to full enteral feeds include a reduced risk of nosocomial infection, thromboembolic complications and PNALD. ${ }^{34}$ Emphasising the latter aspect, results of a recent RCT suggested that time to full enteral feeds is a significant predictor of PNALD in VLBW infants. ${ }^{35}$

Accelerated enteral feeding advancement might also improve weight gain during postnatal hospitalisation. ${ }^{34}$ Currently, available evidence from RCTs and meta-analyses including 588 VLBW infants ${ }^{36}$ does not suggest that moderately fast advancement of enteral feeds increases the incidence of NEC. However, these studies included only a few extremely premature or extremely low birthweight infants. A recent cohort study provided data on the feasibility of transition to full enteral feeds by day 6 in infants with a mean gestational age of 27.7 weeks and a mean birth weight of $894 \mathrm{~g}$ (see table 1 and ref. 16). Adequately powered RCTs in these high-risk infants, assessing the effects of enteral feeding advancement on the incidence of NEC, inhospital mortality, and meaningful long-term outcomes such as growth and neurodevelopment, are urgently needed. In respect thereof, a UK multicentre trial ("Speed of Increasing Feeds Trial", NCT01727609) is projected to enrol 2500 very preterm infants for comparing two rates of daily enteral feeding increments.

In the light of a current meta-analysis, ${ }^{36}$ daily enteral feeding advancement at increments of $20-25-(30) \mathrm{mL} / \mathrm{kg}$ seems reasonable and safe in preterm infants $>1000 \mathrm{~g}$ starting on day 1 (figure 2). This approach was also practised in some of the studies achieving near-fetal postnatal growth summarised in table $1 .{ }^{16}{ }^{18}$ Nevertheless, near-fetal postnatal growth was also achieved with a considerably slower enteral feeding advancement. ${ }^{14}$ Potentially, enteral feeding in infants $<1000 \mathrm{~g}$ can be advanced at comparable rates, ${ }^{16}$ but for these infants highquality data are lacking. A standardised protocol defining feeding increments and handling of feeding difficulties appears to be important $t^{37}$ and repeated enemas to promote meconium 
Figure 2 Early enteral feeding-a

personal view.
Early enteral feeding - a personal view

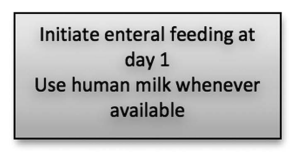

evacuation may be beneficial for an early establishment of full enteral feeds. ${ }^{16}$

\section{Calculation of enteral macronutrient supply on the 1st days after birth}

When practising early and fast enteral feeding advancement, we observed reduced head circumference growth despite higher total protein intake, ${ }^{16}$ possibly indicating insufficient enteral protein absorption. Furthermore, high protein utilisation by the rapidly growing intestine may further decrease systemic protein availability when administered enterally. ${ }^{38}$ Therefore, macronutrient calculation should take into account that absorption and bioavailability of enterally administered nutrients will be incomplete early on. Specifically, providing additional parenteral protein resulting in a total protein intake in excess of $4 \mathrm{~g} / \mathrm{kg} / \mathrm{d}$ during the first postnatal week may be considered whenever relevant amounts of protein are administered enterally.

\section{Start of human milk fortification}

In predominantly human milk-fed VLBW infants, supplementation of human milk with nutrients should best meet the high nutritional requirements of these infants. The use of multicomponent fortifiers promoted enhanced short-term weight gain. ${ }^{39}$ Practices of when to initiate fortification vary considerably and evidence from RCTs favouring one practice over another is lacking. Based on the selected studies achieving near-fetal postnatal growth (table 1) it seems reasonable to start fortification no later than an enteral intake of $100 \mathrm{~mL} / \mathrm{kg} / \mathrm{d}$ has been achieved (figure 2).

\section{Target protein and calorie intake}

Based on the selected studies achieving near-fetal postnatal growth (table 1), an energy intake of $110-140 \mathrm{kcal} / \mathrm{kg} / \mathrm{d}$ seems a reasonable range for many completely enterally fed, otherwise healthy VLBW infants often promoting adequate growth if accompanied by a protein supply of $3.5-4.5 \mathrm{~g} / \mathrm{kg} / \mathrm{d} .{ }^{40}$ Furthermore, a total energy intake of $100 \mathrm{kcal} / \mathrm{kg} / \mathrm{d}$ and a protein supply of $4 \mathrm{~g} / \mathrm{kg} / \mathrm{d}$ within the 1 st week seem to be important goals.

\section{ADDITIONAL AND FUTURE PROSPECTS TO FURTHER IMPROVE EARLY POSTNATAL GROWTH}

Intraindividual and interindividual variability of human milk composition results in deficits in macronutrient and micronutrient supply in some preterm infants potentially entailing shortterm growth deficits with current standardised fortification. ${ }^{41}$ Hence, individualised fortification after macronutrient analyses in human milk might further improve short-term growth. ${ }^{42}$

In infants with insufficient early postnatal weight gain, there might be suboptimal intestinal digestion that could be

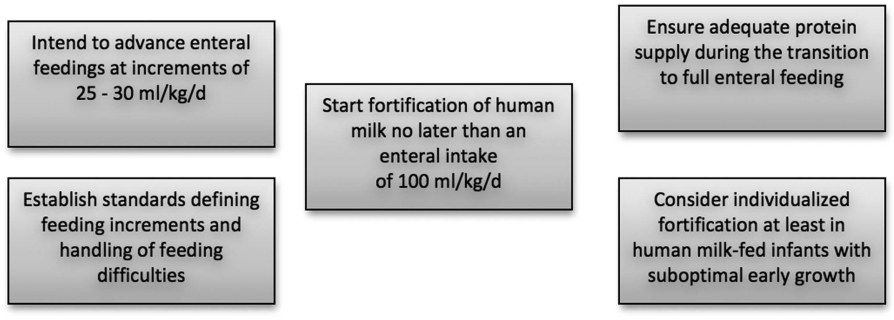

potentially ameliorated by supplementing digestive enzymes. ${ }^{43}$ This may particularly apply to preterm infants fed formula or pasteurised human milk, who may not have the benefit of human milk derived bile-salt stimulated lipase facilitating lipid digestion.

Additionally, adequate supplementation of some key micronutrients has the potential to further optimise early postnatal growth of VLBW infants. In infants with persisting breathing difficulties, procedures to reduce work of breathing, such as provision of continuous positive airway pressure, might ameliorate weight gain. Finally, physical activity programmes were shown to improve short-term weight and length gains in preterm infants. $^{44}$

After nearly approximating fetal weight gain, improvements in body composition (less fat, more lean body mass) come into the focus of nutritional studies in VLBW infants as well as an underappreciated need for key micronutrients potentially enhancing growth, for example, choline or zinc.

Adequately powered RCTs have to show whether an early transition to full enteral feeds has the potential to further improve early postnatal growth while reducing parenteral nutrition associated side effects and complications without increasing the risk of NEC.

\section{CONCLUSIONS}

Regaining birth-growth-trajectories for weight and head circumference until term equivalent age, that is, near-fetal postnatal growth, is feasible in the majority of VLBW infants albeit evidence how this affects long-term metabolic health and neurodevelopment is lacking. Initiation of enhanced parenteral nutrition immediately after birth and capitalising on the large potential of early enteral nutrition seem pivotal. Nevertheless, it remains challenging to further reduce the initial drop in weight and head circumference $\mathrm{z}$-score and to improve body composition and linear growth. Targeted fortification of human milk, administration of digestive enzymes and more attention to micronutrient requirements of VLBW infants may further improve early postnatal growth. Benefits of enhanced nutrition and early transition to enteral feeds regarding long-term, especially neurodevelopmental outcome, remain to be proven in adequately powered RCTs.

Acknowledgements The authors thank Sissel Moltu and Thibault Senterre for providing additional data from their studies and to Birgit Schuler for editorial work.

Contributors CM designed the review, drafted the initial manuscript and revised the manuscript. CFP supervised the project as the head of department and reviewed and revised the manuscript making important intellectual contributions; ARF contributed to review design and revised the manuscript making important intellectual contributions. All authors read and approved the final manuscript.

Competing interests None.

Provenance and peer review Commissioned; externally peer reviewed. 


\section{REFERENCES}

1 Ehrenkranz RA, Dusick AM, Vohr BR, et al. Growth in the neonatal intensive care unit influences neurodevelopmental and growth outcomes of extremely low birth weight infants. Pediatrics 2006;117:1253-61.

2 Franz AR, Pohlandt F, Bode $H$, et al. Intrauterine, early neonatal, and postdischarge growth and neurodevelopmental outcome at 5.4 years in extremely preterm infants after intensive neonatal nutritional support. Pediatrics 2009;123:e101-9.

3 Belfort MB, Rifas-Shiman SL, Sullivan T, et al. Infant growth before and after term: effects on neurodevelopment in preterm infants. Pediatrics 2011;128: e899-906.

4 VanderVeen DK, Martin CR, Mehendale R, et al. Early nutrition and weight gain in preterm newborns and the risk of retinopathy of prematurity. PloS One 2013;8: e64325.

5 Hack M, Schluchter M, Cartar L, et al. Growth of very low birth weight infants to age 20 years. Pediatrics 2003;112(1 Pt 1):e30-8.

6 Singhal A, Cole TJ, Lucas A. Early nutrition in preterm infants and later blood pressure: two cohorts after randomised trials. Lancet 2001;357:413-19.

7 Euser AM, Finken MJ, Keijzer-Veen MG, et al. Associations between prenatal and infancy weight gain and BMI, fat mass, and fat distribution in young adulthood: a prospective cohort study in males and females born very preterm. A J Clin Nutr 2005:81:480-7.

8 Embleton NE, Pang N, Cooke RJ. Postnatal malnutrition and growth retardation: an inevitable consequence of current recommendations in preterm infants? Pediatrics 2001;107:270-3.

9 Ehrenkranz RA, Das A, Wrage LA, et al. Early nutrition mediates the influence of severity of illness on extremely LBW infants. Pediatr Res 2011;69:522-9.

10 Isaacs EB, Morley R, Lucas A. Early diet and general cognitive outcome at adolescence in children born at or below 30 weeks gestation. $J$ Pediatr 2009;155:229-34.

11 Stephens BE, Walden RV, Gargus RA, et al. First-week protein and energy intakes are associated with 18-month developmental outcomes in extremely low birth weight infants. Pediatrics 2009;123:1337-43.

12 Tan M, Abernethy L, Cooke R. Improving head growth in preterm infants - a randomised controlled trial II: MRI and developmental outcomes in the first year. Arch Dis Child Fetal Neonatal Ed 2008;93:F342-6.

13 Morgan C, McGowan P, Herwitker S, et al. Postnatal head growth in preterm infants: a randomized controlled parenteral nutrition study. Pediatrics 2014;133: e120-8.

14 Senterre T, Rigo J. Optimizing early nutritional support based on recent recommendations in VLBW infants and postnatal growth restriction. J Pediatr Gastroenterol Nutr 2011:53:536-42.

15 Loys CM, Maucort-Boulch D, Guy B, et al. Extremely low birthweight infants: how neonatal intensive care unit teams can reduce postnatal malnutrition and prevent growth retardation. Acta Paediatr 2013;102:242-8.

16 Maas C, Mitt S, Full A, et al. A historic cohort study on accelerated advancement of enteral feeding volumes in very premature infants. Neonatology 2013;103:67-73.

17 Vlaardingerbroek H, Vermeulen MJ, Rook D, et al. Safety and efficacy of early parenteral lipid and high-dose amino acid administration to very low birth weight infants. J Pediatr 2013;163:638-44.e1-5.

18 Moltu SJ, Blakstad EW, Strommen K, et al. Enhanced feeding and diminished postnatal growth failure in very-low-birth-weight infants. J Pediatr Gastroenterol Nutr 2014;58:344-51.

19 Cole TJ, Statnikov Y, Santhakumaran S, et al. Birth weight and longitudinal growth in infants born below 32 weeks' gestation: a UK population study. Arch Dis Child Fetal Neonatal Ed 2014;99:F34-40.

20 Moyses HE, Johnson MJ, Leaf AA, et al. Early parenteral nutrition and growth outcomes in preterm infants: a systematic review and meta-analysis. Am J Clin Nutr 2013;97:816-26

21 Burattini I, Bellagamba MP, Spagnoli C, et al. Targeting 2.5 versus $4 \mathrm{~g} / \mathrm{kg} /$ day of amino acids for extremely low birth weight infants: a randomized clinical trial. J Pediatr 2013;163:1278-82.e1.

22 Moltu SJ, Strommen K, Blakstad EW, et al. Enhanced feeding in very-low-birth-weight infants may cause electrolyte disturbances and septicemia--a randomized, controlled trial. Clin Nutr 2013;32:207-12.
23 Trivedi A, Sinn JK. Early versus late administration of amino acids in preterm infants receiving parenteral nutrition. Cochrane Database Syst Rev 2013;7:CD008771.

24 Tang ZF, Huang $Y$, Zhang $R$, et al. [Intensive early amino acid supplementation is efficacious and safe in the management of preterm infants]. Zhonghua er ke za zhi 2009;47:209-15.

25 Vlaardingerbroek $H$, Veldhorst MA, Spronk S, et al. Parenteral lipid administration to very-low-birth-weight infants--early introduction of lipids and use of new lipid emulsions: a systematic review and meta-analysis. Am J Clin Nutr 2012:96:255-68.

26 Drenckpohl D, McConnell C, Gaffney S, et al. Randomized trial of very low birth weight infants receiving higher rates of infusion of intravenous fat emulsions during the first week of life. Pediatrics 2008;122:743-51.

27 Vlaardingerbroek H, Vermeulen MJ, Carnielli VP, et al. Growth and Fatty Acid Profiles of VLBW Infants Receiving a Multicomponent Lipid Emulsion From Birth. J Pediatr Gastroenterol Nutr 2014;58:417-27.

28 Vlaardingerbroek $\mathrm{H}, \mathrm{Ng} \mathrm{K}$, Stoll B, et al. New generation lipid emulsions prevent PNALD in chronic parenterally fed preterm pigs. J Lipid Res 2014;55:466-77.

29 Koletzko B, Goulet O, Hunt J, et al. 1. Guidelines on Paediatric Parenteral Nutrition of the European Society of Paediatric Gastroenterology, Hepatology and Nutrition (ESPGHAN) and the European Society for Clinical Nutrition and Metabolism (ESPEN), Supported by the European Society of Paediatric Research (ESPR). J Pediatr Gastroenterol Nutr 2005:41(Suppl 2):S1-87.

30 Sinclair JC, Bottino M, Cowett RM. Interventions for prevention of neonatal hyperglycemia in very low birth weight infants. Cochrane Database Syst Rev 2011; (10):CD007615.

31 Bonsante $F$, lacobelli S, Latorre $G$, et al. Initial amino acid intake influences phosphorus and calcium homeostasis in preterm infants--it is time to change the composition of the early parenteral nutrition. PloS One 2013;8:e72880.

32 Rigo J, Senterre T. Intrauterine-like growth rates can be achieved with premixed parenteral nutrition solution in preterm infants. J Nutr 2013;143(12 Suppl):2066S-70S.

33 Morgan J, Young L, McGuire W. Delayed introduction of progressive enteral feeds to prevent necrotising enterocolitis in very low birth weight infants. Cochrane Database Syst Rev 2013;5:CD001970.

34 Leaf A, Dorling J, Kempley S, et al. Early or delayed enteral feeding for preterm growth-restricted infants: a randomized trial. Pediatrics 2012;129:e1260-8.

35 Salvador A, Janeczko M, Porat $R$, et al. Randomized controlled trial of early parenteral nutrition cycling to prevent cholestasis in very low birth weight infants. J Pediatr 2012;161:229-33.e1.

36 Morgan J, Young L, McGuire W. Slow advancement of enteral feed volumes to prevent necrotising enterocolitis in very low birth weight infants. Cochrane Database Syst Rev 2013;3:CD001241.

37 Patole SK, de Klerk N. Impact of standardised feeding regimens on incidence of neonatal necrotising enterocolitis: a systematic review and meta-analysis of observational studies. Arch Dis Child Fetal Neonatal Ed 2005:90:F147-51.

38 van der Schoor SR, Schierbeek H, Bet PM, et al. Majority of dietary glutamine is utilized in first pass in preterm infants. Pediatr Res 2010;67:194-9.

39 Kuschel CA, Harding JE. Multicomponent fortified human milk for promoting growth in preterm infants. Cochrane Database Syst Rev 2004;(1):CD000343.

40 Agostoni C, Buonocore G, Carnielli VP, et al. Enteral nutrient supply for preterm infants: commentary from the European Society of Paediatric Gastroenterology, Hepatology and Nutrition Committee on Nutrition. J Pediatr Gastroenterol Nutr 2010;50:85-91.

41 Maas C, Wiechers C, Bernhard W, et al. Early feeding of fortified breast milk and in-hospital-growth in very premature infants: a retrospective cohort analysis. $B M C$ Pediatr 2013;13:178.

42 Rochow N, Fusch G, Choi A, et al. Target fortification of breast milk with fat, protein, and carbohydrates for preterm infants. J Pediatr 2013;163:1001-7.

43 Carnielli VP, Casper C, Vagero M, et al. A Combined Analysis of Data from Two Studies Comparing rhBSSL (Recombinant Human Bile Salt Stimulated Lipase) and Placebo Added to Infant Formula or Pasteurized Breast Milk in Preterm Infants. Presented at PAS-Meeting 2011, E-PAS20113670.8, 2011.

44 Schulzke SM, Kaempfen S, Trachsel D, et al. Physical activity programs for promoting bone mineralization and growth in preterm infants. Cochrane Database Syst Rev 2014;4:CD005387. 